\title{
WT1 Peptide Vaccine WT2725
}

National Cancer Institute

\section{Source}

National Cancer Institute. WT1 Peptide Vaccine WT2725. NCI Thesaurus. Code C102751.

A peptide cancer vaccine comprised of a peptide derived from Wilms tumor gene 1 (WT 1) protein, with potential immunomodulating and antineoplastic activities. Upon administration, WT 2725 may induce a specific cytotoxic T-lymphocyte (CTL) response against WT 1-overexpressing tumor cells. WT 1 protein, a zinc finger DNA-binding protein, is overexpressed in leukemic cells and in a vast number of non-hematological solid tumors. 